\title{
ENRICHMENT OF THE FATTY ACIDS PROFILE OF BREADS REPLACED WITH FUNCTIONAL FLOURS BLENDS
}

\author{
MB Osuna ${ }^{1}$, AM Romero ${ }^{2}$, MA Judis ${ }^{3}$, NC Bertola ${ }^{4}$ \\ ${ }^{1}$ Professor, Laboratory of Food Industry, Department of Basics and Applied Sciences, Chaco Austral National \\ University, ComandanteFernández, Chaco, Argentina \& Researcher, CONICET (Consejo Nacional de \\ Investigaciones Científicas y Técnicas) Argentina. \\ ${ }^{2}$ Professor, Laboratory of Food Industry, Department of Basics and Applied Sciences, Chaco Austral National \\ University, ComandanteFernández, Chaco, Argentina \\ ${ }^{3}$ Professor, Laboratory of Food Industry, Department of Basics and Applied Sciences, Chaco Austral National \\ University, ComandanteFernández, Chaco, Argentina \\ ${ }^{4}$ Researcher, CONICET (Consejo Nacional de Investigaciones Científicas y Técnicas) Argentina \& Professor, \\ CIDCA, Faculty of Exact Sciences, National University of La Plata - La Plata, Buenos Aires, Argentina.
}

\begin{abstract}
Functional breads constitute an interesting alternative as a vehicle of new essential fatty acid sources. The aim of this study was to improve the fatty acids profile of breads replaced with mixtures of three flours and to analyse the effect of their use on texture parameters, colour and technological characteristics of these products. Wheat flour $(W F)$ was replaced with mixtures of soybean flour $(S F)$, flaxseed flour $(F F)$ and wheat bran (WB). A multilevel factorial design with 3 factors $(F F, S F$ and WB) and 3 levels $(0$ $\mathrm{g} / \mathrm{Kg} W F-8 \mathrm{~g} / \mathrm{KgWF}-16 \mathrm{~g} / \mathrm{Kg} \mathrm{WF})$ were applied; being bread without flour replacement, the control sample. The content of saturated fatty acids (SFA) decreased with increasing concentration of $F F$, while the content of polyunsaturated fatty acids (PUFA) tended to increase at higher contents of SF and FF. The breads substituted with the highest concentration of FF in mixtures $F F+S F$ or $F F+W B$ showed the highest of $n 3$ fatty acid content. Specific volume of breads with the blends $F F+S F$ and $F F+W B$ showed no significant differences with control ( $p<0.05)$. The samples with $16 \mathrm{~g} / \mathrm{kg} \mathrm{FF+16} \mathrm{g/kg} \mathrm{WB} \mathrm{and} \mathrm{with} 16 \mathrm{~g} / \mathrm{Kg}$ $F F+8 \mathrm{~g} / \mathrm{Kg} S F$ were selected for high content $n 3$ and good specific volume. These breads presented harder crumb, less cohesiveness and more chewiness. Colour crumb was more reddish in bread with $F F+W B$, more yellowish in bread with $F F+S F$, and both lesser luminous than the control. Although these selected formulations provided breads with high content n3, their crumbs were darker and harder than wheat flour bread.
\end{abstract}

Keywords: Omega-3 Fatty Acids; Functional Breads; Flaxseed; Bread Formulation; Flour Mixture.

\section{INTRODUCTION}

Today the technologies to improve food nutritionally and nutraceuticals are optimized by industry and researchers, as consumers seek healthy foods that can prevent noncommunicable diseases [1].

Functional foods are regarded as innovative and promising products, which in addition to providing needed for basic nutrition, act beneficially on certain body functions [2]. These positive impacts can help to prevent or decrease the risk of heart diseases, cardiovascular problems, constipation, diabetes and so on [3].

Flaxseed is emerging as an important functional food ingredient due to its high content of $\alpha$-linolenic acid (ALA, n3 fatty acid), lignans and fibre. Flaxseed oil, flax fibre and lignans also have potential health benefits, for this purpose, these have been incorporated into meat products, juices, milk and dairy products, dry pasta, macaroni, muffins and baked goods, for preparing functional foods [4].

Soy products complement the amino acid profile of cerealbased products, as they are a source of protein and therefore bring benefits to human health [5]. Furthermore, soy presents high amounts of dietary fiber, flavonoids, isoflavones, saponins soy and other antioxidant compounds, that assist in the prevention of chronic diseases as osteoporosis and cancer. However, the quality (loaf volume, crumb grain, retention of freshness and flavour) as well as the acceptance of the loaves is affected when high levels of soy are used in its formulation [6].

Whole grains compared to refined grains, have greater health benefits, this can be attributed to the inclusion of the outer layers of the grain, bran. This is rich in most micronutrients, phytochemicals, and fibre of the grain. [7]. Bran is a by-product of the milling industry wheat and has a high content of valuable secondary metabolites of plants and is an excellent source of dietary fibre. Although used in the preparation of baked goods, its main use is as an animal feed supplement. [8]. Reinsertion of wheat bran in the food industry is a strategy to encourage the intake of dietary fibre on consumers. Wheat bran can also extract oil, that is used in the food industry, pharmaceutical and cosmetic industry, because it is particularly rich in polyunsaturated fatty acids, vitamin E, carotenoids, and quinones[9]. Therefore, wheat bran has interest both from the point of view of public health and the economic, as it could increase its value in milling industry [10]. 
In recent years, the trend has been towards increased consumption of refined vegetable oils such as soybean and canola, as a source of fat in the diet to reduce the intake of animal fat. These changes in the diet, have led to a significant increase in n6: $\mathrm{n} 3$ ratio of fatty acids 15: 1 and 20: 1 , whereas proportions closer to 2: 1 and 4: 1 have been recommended by the WHO [11]. This imbalance is related to the incidence of many chronic diseases such as hypertension, obesity, inflammatory diseases and cancers [12].

Due to the high unsaturated fatty acids content of the flaxseed, soybeans and wheat bran, the fortification of foods with these grains can be a good way to increase the polyunsaturated fatty acids content of the processed foods. Nowadays, consumers prefer to consume superior quality foods and healthy foods, so the tendency in baked products is to produce specialty breads made from whole grain flour and other functional ingredients [13]. Bread, food that is universally consumed, can be also a convenient vehicle for introducing $\mathrm{n} 3$ fatty acids into the diet due to that this offers a stable environment for PUFA by its relatively low moisture and short shelf-life [14].

There is enough literature available on nutritional characterization of flaxseed, soybeans, chia, wheat bran, and others grains [3-10] and their utilization in processed foods $[23,24]$ [29 - 37]. Nevertheless, knowledge about the effect of supplementation of wheat flour with combinations of different flours as flaxseed flour, soy and wheat bran for bread making are scant.

Therefore, the aim of this study was to improve the fatty acids profile of breads replaced with mixtures of three flours and to analyse the effect of their use on texture parameters, colour and technological characteristics of these products.

\section{MATERIALS AND METHODS}

\subsection{Materials}

Commercial wheat flour (WF) Florencia $^{\circledR}$, Argentina) utilized for all experiments was provided local commercial. Wheat flour parameters were: tenacity $(\mathrm{P})=135 \mathrm{~mm}$, extensibility $(\mathrm{L})=61 \mathrm{~mm}, \mathrm{P} / \mathrm{L}=2.21$, deformation energy $(\mathrm{W})=334 \times 10^{-4} \mathrm{~J}[15]$, moisture $=13.6 \pm 0.2 \%$ and protein $=11 \pm 0.3 \%$ (Kjeldahl method, $\mathrm{N} \times 5.7$ ). Whole soybean flour (SF) (Ricedal Alimentos ${ }^{\circledR}$, Argentina), whole flaxseed flour (FF) (Vicentin $^{\circledR}$, Argentina), wheat bran (WB) (Avecon $^{\circledR}$, Argentina) and bovine fat (BF) (Friar ${ }^{\circledR}$, Argentina) were used for the preparation of the breads. Compressed yeast (Saccharomyces cerevisiae, Calsa ${ }^{\circledR}$, Argentina), sodium chloride (Celusal ${ }^{\circledR}$, Argentina) was used as leavening agent. The moisture content of yeast was $71.5 \%$.

\subsection{Methods}

\subsubsection{Experimental Design}

A multilevel factorial design with 3 factors (FF, SF and WB) and 3 levels $(0 \mathrm{~g} / \mathrm{Kg} \mathrm{WF}-8 \mathrm{~g} / \mathrm{Kg} \mathrm{WF}-16 \mathrm{~g} / \mathrm{Kg} \mathrm{WF})$ was applied and 27 bread formulations were prepared (Table 1). The control sample contained $100 \%$ WF (sample 8).

\subsubsection{Bread Making Procedure}

The process used was the direct method[16]. The different steps were performed at laboratory scale. The bread dough was prepared with commercial wheat flour $(1000 \mathrm{~g})$ partially replaced by the mixes of the three flours - SF, FF and WB - according to the adopted design. Compressed yeast (40 g), fat bovine (40 g), sodium chloride (20 g) and potable water until reach the optimum absorption, about 55 $\mathrm{g}$ of water/100 $\mathrm{g}$ of flour, were also added.

The ingredients were mixed and kneaded to an optimum consistency in a rapid mixer (Zonda ${ }^{\circledR}$, Buenos Aires, Argentina) during $7 \mathrm{~min}$, and then they were put to rest for $15 \mathrm{~min}$. After this period, the dough was laminated into the laminator $\left(\mathrm{Rd}^{\circledR}\right.$, Buenos Aires, Argentina) and allowed to stand for $15 \mathrm{~min}$ again. Then, the dough was divided into portions of $400 \mathrm{~g}$, was rounded manually, and was allowed to stand for $15 \mathrm{~min}$ more. They were cut in portions of $200 \mathrm{~g}$ and the loaves were armed and placed into aluminium pans $(24.5 \times 6.5 \mathrm{~cm})$. The pans were placed in a fermentation chamber at $35^{\circ} \mathrm{C}$ and $85 \%$ Relative Humidity (RH) for 90 min. The fermented loaves were baked in an electric oven (Zonda ${ }^{\circledR}$, Buenos Aires, Argentina) for $15 \mathrm{~min}$ at $180 \pm 5^{\circ} \mathrm{C}$. After baking, the breads were removed from the pans and cooled to room temperature $\left(25 \pm 1^{\circ} \mathrm{C}\right)$ and packed into polyethylene bags for their subsequent analysis. The experiment was replicated twice.

Table - 1: Multilevel factorial design $3^{3}$ used for evaluating bread quality of flours blend

\begin{tabular}{|l|l|l|l|l|l|l|}
\hline \multirow{2}{*}{ Samples } & \multicolumn{7}{|l}{ Coded } & FF & SF & WB & $\begin{array}{l}\text { FF } \\
\text { (g/Kg } \\
\text { WF })\end{array}$ & $\begin{array}{l}\text { SF } \\
\text { (g/Kg } \\
\text { WF })\end{array}$ & $\begin{array}{l}\text { WB } \\
\text { (g/Kg } \\
\text { WF })\end{array}$ \\
\hline $\mathbf{1}$ & 1 & 1 & 1 & 16 & 16 & 16 \\
\hline $\mathbf{2}$ & -1 & 1 & 1 & 0 & 16 & 16 \\
\hline $\mathbf{3}$ & -1 & 0 & 1 & 0 & 8 & 16 \\
\hline $\mathbf{4}$ & -1 & 0 & 0 & 0 & 8 & 8 \\
\hline $\mathbf{5}$ & 0 & 0 & 0 & 8 & 8 & 8 \\
\hline $\mathbf{6}$ & 0 & 1 & 0 & 8 & 16 & 8 \\
\hline $\mathbf{7}$ & 0 & -1 & -1 & 8 & 0 & 0 \\
\hline $\mathbf{8}$ & -1 & -1 & -1 & 0 & 0 & 0 \\
\hline $\mathbf{9}$ & 1 & -1 & 0 & 16 & 0 & 8 \\
\hline $\mathbf{1 0}$ & 0 & 0 & -1 & 8 & 8 & 0 \\
\hline $\mathbf{1 1}$ & -1 & 0 & -1 & 0 & 8 & 0 \\
\hline $\mathbf{1 2}$ & 1 & 0 & 0 & 16 & 8 & 8 \\
\hline $\mathbf{1 3}$ & 0 & -1 & 0 & 8 & 0 & 8 \\
\hline $\mathbf{1 4}$ & 1 & 1 & 0 & 16 & 16 & 8 \\
\hline $\mathbf{1 5}$ & 0 & 1 & 1 & 8 & 16 & 16 \\
\hline $\mathbf{1 6}$ & 0 & -1 & 1 & 8 & 0 & 16 \\
\hline $\mathbf{1 7}$ & -1 & 1 & -1 & 0 & 16 & 0 \\
\hline $\mathbf{1 8}$ & -1 & -1 & 0 & 0 & 0 & 8 \\
\hline $\mathbf{1 9}$ & 0 & 1 & -1 & 8 & 16 & 0 \\
\hline $\mathbf{2 0}$ & 1 & 0 & 1 & 16 & 8 & 16 \\
\hline $\mathbf{2 1}$ & 1 & 1 & -1 & 16 & 16 & 0 \\
\hline $\mathbf{2 2}$ & -1 & -1 & 1 & 0 & 0 & 16 \\
\hline $\mathbf{2 3}$ & 1 & -1 & 1 & 16 & 0 & 16 \\
\hline $\mathbf{2 4}$ & 0 & 0 & 1 & 8 & 8 & 16 \\
\hline $\mathbf{2 5}$ & 1 & -1 & -1 & 16 & 0 & 0 \\
\hline $\mathbf{2 6}$ & -1 & 1 & 0 & 0 & 16 & 8 \\
\hline & & & & & & \\
\hline
\end{tabular}




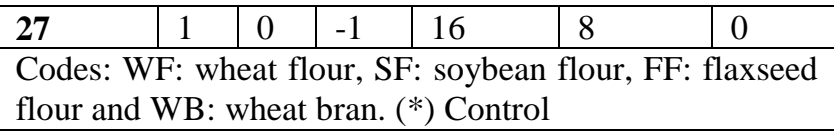

\subsubsection{Bread Analyses}

\subsubsection{Fatty Acids Composition}

Total lipids were extracted from breads using the Bligh \& Dyer [17] method. The lipids extracted were converted into fatty acids methyl esters, according to the methodology proposed by AOAC [18]. Fatty acid composition was determined using an Agilent gas chromatograph (model 6850A HP, Agilent Technologies Inc, CA, USA), equipped with a $60 \mathrm{~m}$ Supelco ${ }^{\circledR} 2340$ capillary column. The temperature of the injector and the detector was kept at 240 ${ }^{\circ} \mathrm{C}$. The injected volume was $1.0 \mu \mathrm{l}$. The carrier gas was helium at $0.6 \mu 1 \mathrm{~min}^{-1}$. The Split ratio used was 1:100. The temperature of the column was kept at $140{ }^{\circ} \mathrm{C}$ for 5 minutes, raised to $240{ }^{\circ} \mathrm{C}$ at $4{ }^{\circ} \mathrm{C} / \mathrm{min}$, and maintained at $240{ }^{\circ} \mathrm{C}$ for 10 minutes. Fatty acids (FA) were identified by comparison of their retention times with international standards (Supelco 37 Components FAME Mix ${ }^{\circledR}$, Bellefonte, PA), and reported as $\mathrm{g} / 100 \mathrm{~g}$ of total fatty acids. Results were expressed as relative quantities of SFA, MUFA, and PUFA; PUFA/SFA ratio; and $\mathrm{n} 6 / \mathrm{n} 3$ ratio [19].

\subsubsection{Technological Parameters}

Technological parameters were carried out according to American Association of Cereal Chemists (AACC) [15]. Moisture contents of bread were determined by measuring their weight loss after drying in an oven at $130^{\circ} \mathrm{C}$ until reaching constant weight. Samples of bread were analysed and results were expressed in grams of water per $100 \mathrm{~g}$ of wet product [15]. The specific volume (SV) of the bread was determined by the flaxseed volume displacement divided by the sample weight $\left(\mathrm{cm}^{3} / \mathrm{g}\right)$, according to the AACC method $10-05$ [15].The width and height of the central slices $(n=3)$ were measured with a calibre and the width/height ratios were obtained. Water activities of the bread crumbs were determined at $25{ }^{\circ} \mathrm{C}$ by Humidity Meter (TESTO 650, USA).

\subsubsection{Selection of Formulations}

Formulations with the highest $\mathrm{n} 3$ fatty acid concentration and good specific volume were selected for the following analysis.

\subsubsection{Breadcrumb Texture Profile Analysis}

Texture measurements were carried out on cylinder $(20 \mathrm{~mm}$ of diameter and $20 \mathrm{~mm}$ height), cut from the central part of the three slices of loaves for each formulation, $15 \mathrm{~h}$ after baking. An average of six measurements per sample was made. The bread cylinders were compressed using a Textural Analyser (CT3, Brookfield, USA) equipped with TA25/1000 acrylic cylinder probe (50.8 mm diameter). For texture profile analysis (TPA), samples were compressed to $50 \%$ of their original height. The uniaxial compression test was performed in two successive cycles, using a test speed of $0.5 \mathrm{~mm} / \mathrm{s}$ [16]. The typical texture profile analysis parameters: hardness $(\mathrm{N})$, cohesiveness (dimensionless), springiness $(\mathrm{mm})$ and chewiness $(\mathrm{mJ})$ were determined from the Force-Distances curves and calculated with the instrumental software [20].

\subsubsection{Colour Analysis}

The colour of crumb and crust of breads was determined with a Thermo Scientific Spectrophotometer with an integrating sphere (Hunter Associates Laboratory, Inc., Reston, VA) and the results were expressed according to the CIELab system with a D65 lamp and $10^{\circ}$ visual angle as reference. The parameters $\mathrm{L}^{*}$ (lightness), a* (redness), and $\mathrm{b}^{*}$ (yellowness) were used to calculate the browning index (BI) according toKomlenic[21], as follow:

$$
\begin{gathered}
B I=\frac{100 \times(x-0,31)}{0,17} \\
x=\frac{\left(a^{*}+1,75 \times L^{*}\right)}{5,645 \times L^{*}+a^{*}-3,012 \times b^{*}}
\end{gathered}
$$

\subsubsection{Statistical Analysis}

The statistical analysis was performed by INFOSTAT statistical software (Facultad de CienciasAgropecuarias, UNC, Argentina). Determinations were done at least three times. In order to evaluate differences among samples ( $\mathrm{p}<$ 0.05) the Tukey's test was performed.

\section{RESULTS AND DISCUSION}

\subsection{Fatty Acid Composition of Breads replaced with}

\section{Mixtures of Three Flours}

Table 2 and 3 shows the relative quantities of the identified fatty acids, as well as total contents of SFA, MUFA, PUFA, $\mathrm{n} 3, \mathrm{n} 6, \mathrm{n} 9(\mathrm{~g} / 100 \mathrm{~g}$ of total fatty acids) and relationship PUFA/SFA and $n 6 / n 3$ of loaves replaced with mixtures of three flours (FF - SF - WB).The incorporation of notraditional flours in breads formulations produced changes in the composition of fatty acids and in the total content of SFA, MUFA, PUFA, n3, n6, n9 and its relations PUFA/SFA and n6/n3.All parameters showed significant differences with control (sample8).

MUFA content decreased in most samples when wheat flour was replaced. However, mixture with $\mathrm{SF}+\mathrm{WB}$ produced an increase of MUFA.On the other hand, PUFA content mainly tended to increase with increasing level of SF and FF. The essential PUFAs to humans are those having double bonds in the $\mathrm{n} 6$ and $\mathrm{n} 3$ positions. The $\alpha$-linolenic acid (18:3 n3) gives rise to long chain derivatives, which are eicosapentaenoic acid (EPA, 20:5 n3) and docosahexaenoic (DHA, 22:6 n3). They are among the most physiologically important, being the EPA mainly associated with cardiovascular health and the DHA with the formation and function of the nervous and visual tissues[22].

The addition of mixtures of flours to the formulations of breads produced an increase in the linolenic fatty acid content (18:3 n3) in most samples compared to the control, being greater in breads with blends of high FF level with high concentrations of WB or SF. 


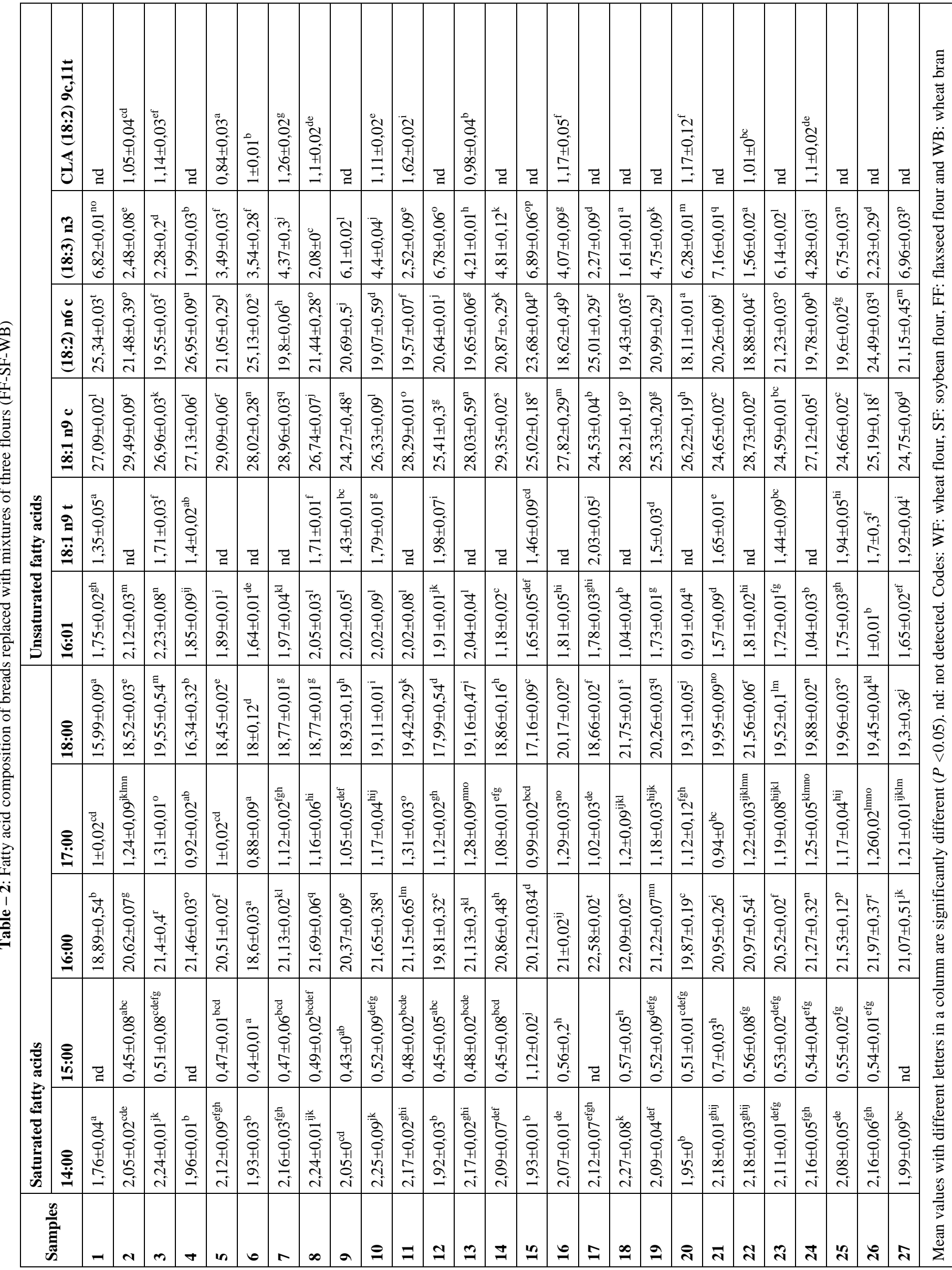


The sample with the highest linolenic fatty acid content, presented an amount 3 times higher $(245 \%)$ than the control.These results were consistentwith Bautista Justo et al. [23], who found that loaves added with mixtures of $10 \%$ SF and 5\% FF caused an increase of $208 \%$ in the linolenic acid content, while bread substituted with mixtures of $10 \%$ $\mathrm{FF}, 5 \% \mathrm{FF}$ and $5 \%$ flour chia produced a $400 \%$ increase in the content of the fatty acid with respect to the control bread.The linoleic fatty acid $(18: 2 \mathrm{n} 6 \mathrm{c})$ tended to decrease in most breads with FF added, while was increased with the addition of SF in high concentrations or mixtures SF+WB. These results were consistent with Gomes Natal et al. [24]. All samples had beef fat, so the conjugated linolenic acid (CLA) should had been detectedsince it is a characteristic component of fats from ruminants [25], however, in samples with high concentrations of FF were not detected, which could be due to the relative decrease of this fatty acid to total fatty acid content.

The western diets often contain a proportion of $n 6 / n 3$ fatty acids about $10 / 1$ to $25 / 1$, indicating a considerable deficiency $n 3$ fatty acids. The optimum ratio of n6 / n3 fatty acids should be about 4.1 to 1.1 for the prevention of various pathologies. [26].

The addition of flax to the formulations of studied breads had a significant effect on decrease of $n 6 / n 3$ ratio, so that in breads with $\mathrm{FF}$ and its mixtures, the ratio decreased to 2.5/1 due to its high content of $n 3$ fatty acids, while that, the breads with high concentrations of WB or SF $y$ their mixtures (SF-WB) showed values between 11 and 14, due to high content of fatty acids $n 6$ of these ingredients.

By being the relationship between the unsaturated fatty acids of great importance in terms of diet and the balance of fats in the body, consuming the experimental bread with FF and their blends would help to increase the omega- 3 intake in the dietary habits of western populations. To indicate whether a particular food is healthy, the PUFA / SFA ratio should be greater than 0.45 according to the World Health Organization [27]. The PUFA/SFA ratios of breads substituted with FF, SF y their blends were within these recommended values. Samples with the highest level of three flours presented the highest ratio $(0.85)$.

Table - 3: Total contents of SFA, MUFA, PUFA, n3, n6, n9 and relationship PUFA /SFA and n6/n3of breads replaced with mixtures of three flours (FF-SF-WB)

\begin{tabular}{|c|c|c|c|c|c|c|c|c|}
\hline Samples & SFA & MUFA & PUFA & n3 & n6 & n9 & PUFA/SFA & n6/n3 \\
\hline 1 & $37,64 \pm 0,04^{\mathrm{a}}$ & $30,21 \pm 0,49^{\mathrm{ef}}$ & $32,19 \pm 0,03^{\mathrm{p}}$ & $6,82 \pm 0,04^{\mathrm{no}}$ & $25,36 \pm 0,02^{\mathrm{u}}$ & $27,09 \pm 0,18^{1}$ & $0.85^{\mathrm{u}}$ & $3.72^{\mathrm{e}}$ \\
\hline 2 & $42,88 \pm 0,03^{\mathrm{e}}$ & $32,12 \pm 0,18^{1}$ & $23,99 \pm 0,19^{f}$ & $2,48 \pm 0,04^{\mathrm{e}}$ & $21,5 \pm 0,03^{\mathrm{P}}$ & $29,49 \pm 0,01^{\mathrm{t}}$ & $0.56^{\mathrm{h}}$ & $8.67^{1}$ \\
\hline 3 & $45,55 \pm 0,06^{\mathrm{m}}$ & $31,49 \pm 0,03^{\mathrm{jk}}$ & $21,86 \pm 0,38^{b}$ & $2,28 \pm 0,05^{\mathrm{d}}$ & $19,57 \pm 0,01^{\mathrm{f}}$ & $26,96 \pm 0,06^{\mathrm{k}}$ & $0.48^{\mathrm{b}}$ & $8.58^{1}$ \\
\hline 4 & $40,68 \pm 0,54^{\mathrm{c}}$ & $30,39 \pm 0,56^{\mathrm{fg}}$ & $28,97 \pm 0,18^{\mathrm{n}}$ & $1,99 \pm 0,08^{b}$ & $26,97 \pm 0,01^{\mathrm{w}}$ & $27,13 \pm 0,08^{1}$ & $0.71^{\mathrm{s}}$ & $13.58^{\mathrm{p}}$ \\
\hline 5 & $42,55 \pm 0,12^{\mathrm{e}}$ & $32,08 \pm 0,38^{\mathrm{KI}}$ & $29,09 \pm 0,18^{\mathrm{n}}$ & $3,49 \pm 0,01^{\mathrm{f}}$ & $21,07 \pm 0,03^{\mathrm{m}}$ & $29,09 \pm 0,02^{r}$ & $0.68^{\mathrm{q}}$ & $6.04^{i}$ \\
\hline 6 & $39,82 \pm 0,04^{b}$ & $30,54 \pm 0,08^{\text {fgh }}$ & $28,06 \pm 0,09^{\operatorname{Im}}$ & $3,54 \pm 0,03^{f}$ & $25,15 \pm 0,19^{t}$ & $28,02 \pm 0,18^{\mathrm{n}}$ & $0.7^{\mathrm{r}}$ & $7.1^{j}$ \\
\hline 7 & $43,65 \pm 0,07^{\text {gh }}$ & $30,95 \pm 0,09^{\text {ghij }}$ & $29 \pm 0,18^{n}$ & $4,37 \pm 0,39^{j}$ & $19,82 \pm 0,29^{\mathrm{h}}$ & $28,96 \pm 0,02^{j}$ & $0.66^{\mathrm{P}}$ & $4.54^{\mathrm{gh}}$ \\
\hline 8 & $44,35 \pm 0,07^{j}$ & $31,04 \pm 0,09^{\text {hij }}$ & $23,56 \pm 0,18^{\mathrm{e}}$ & $2,08 \pm 0,02^{\mathrm{c}}$ & $21,46 \pm 0,09^{\mathrm{p}}$ & $26,74 \pm 0,02^{j}$ & $0.53^{\mathrm{e}}$ & $10.32^{\mathrm{m}}$ \\
\hline 9 & $42,84 \pm 0,09^{\mathrm{e}}$ & $28,28 \pm 0,09^{b}$ & $20,77 \pm 0,18^{j}$ & $6,1 \pm 0,01^{1}$ & $20,69 \pm 0,04^{\mathrm{k}}$ & $24,27 \pm 0,02^{\mathrm{a}}$ & $0.56^{\mathrm{h}}$ & $2.52^{\mathrm{a}}$ \\
\hline 10 & $44,72 \pm 0,03^{k}$ & $30,72 \pm 0,02^{\text {fghi }}$ & $23,5 \pm 0,29^{\mathrm{e}}$ & $4,4 \pm 0,04^{\mathrm{j}}$ & $19,09 \pm 0,09^{d}$ & $26,33 \pm 0,33^{i}$ & $0.53^{\mathrm{e}}$ & $4.34^{\mathrm{f}}$ \\
\hline 11 & $44,54 \pm 0,04^{\mathrm{jk}}$ & $31,19 \pm 0,02^{\mathrm{ij}}$ & $22,69 \pm 0,03^{\mathrm{c}}$ & $2,52 \pm 0,14^{\mathrm{e}}$ & $19,59 \pm 0,05^{\mathrm{fg}}$ & $28,29 \pm 0,34^{\circ}$ & $0.51^{\mathrm{c}}$ & $7.79^{\mathrm{k}}$ \\
\hline 12 & $43,3 \pm 0,18^{f}$ & $29,31 \pm 0,2^{\mathrm{cd}}$ & $27,45 \pm 0,03^{\mathrm{k}}$ & $6,78 \pm 0,12^{\mathrm{n}}$ & $20,66 \pm 0,02^{\mathrm{k}}$ & $25,41 \pm 0,32^{\mathrm{g}}$ & $0.63^{\mathrm{m}}$ & $3.05^{\mathrm{c}}$ \\
\hline 13 & $44,23 \pm 0,54^{\mathrm{ij}}$ & $30,96 \pm 0,3^{\text {ghij }}$ & $23,89 \pm 0,03^{f}$ & $4,21 \pm 0,02^{h}$ & $19,67 \pm 0,03^{\mathrm{g}}$ & $28,03 \pm 0,03^{\mathrm{n}}$ & $0.54^{\mathrm{f}}$ & $4.67^{\mathrm{h}}$ \\
\hline 14 & $43,36 \pm 0,32^{\mathrm{fg}}$ & $30,99 \pm 0,01^{\text {ghij }}$ & $25,71 \pm 0,3^{\mathrm{h}}$ & $4,81 \pm 0,04^{\mathrm{k}}$ & $20,89 \pm 0,32^{1}$ & $29,35 \pm 0,18^{\mathrm{s}}$ & $0.59^{\mathrm{k}}$ & $4.34^{\mathrm{f}}$ \\
\hline 15 & $41,32 \pm 0,27^{\mathrm{d}}$ & $28,14 \pm 0,5^{\mathrm{ab}}$ & $30,6 \pm 0,03^{\circ}$ & $6,89 \pm 0,01^{\mathrm{op}}$ & $23,7 \pm 0,19^{q}$ & $25,02 \pm 0,09^{\mathrm{e}}$ & $0.74^{\mathrm{t}}$ & $3.44^{\mathrm{d}}$ \\
\hline 16 & $45,1 \pm 0,18^{1}$ & $30,5 \pm 0,18^{\mathrm{fgh}}$ & $23,28 \pm 0,02^{\mathrm{d}}$ & $4,07 \pm 0,04^{\mathrm{g}}$ & $18,64 \pm 0,12^{b}$ & $27,82^{\mathrm{m}}$ & $0.52^{\mathrm{d}}$ & $4.57^{\mathrm{gh}}$ \\
\hline 17 & $44,4 \pm 0,43^{\mathrm{jk}}$ & $28,35 \pm 0,32^{b}$ & $27,31 \pm 0,03^{\mathrm{k}}$ & $2,27 \pm 0,1^{\mathrm{d}}$ & $25,03 \pm 0,12^{\mathrm{s}}$ & $24,53 \pm 0,78^{b}$ & $0.61^{1}$ & $11.05^{\mathrm{n}}$ \\
\hline 18 & $47,89 \pm 0,04^{\circ}$ & $29,79 \pm 0,2^{\mathrm{de}}$ & $21,07 \pm 0,02^{\mathrm{a}}$ & $1,61 \pm 0,09^{\mathrm{a}}$ & $19,45 \pm 0,39^{\mathrm{e}}$ & $28,21 \pm 0,21^{\circ}$ & $0.45^{\mathrm{a}}$ & $12.08^{\circ}$ \\
\hline 19 & $45,27 \pm 0,19^{\operatorname{lm}}$ & $29 \pm 0,12^{c}$ & $25,77 \pm 0,03^{\mathrm{h}}$ & $4,75 \pm 0,01^{\mathrm{k}}$ & $20,99 \pm 0,28^{\mathrm{m}}$ & $25,33 \pm 0,18^{\mathrm{g}}$ & $0.57^{1}$ & $4.42^{\mathrm{fg}}$ \\
\hline 20 & $42,77 \pm 0,12^{\mathrm{e}}$ & $27,58 \pm 0,19^{a}$ & $24,72 \pm 0,09^{\mathrm{g}}$ & $6,28 \pm 0,01^{\mathrm{m}}$ & $18,43 \pm 0,18^{\mathrm{a}}$ & $26,22 \pm 0,05^{\mathrm{h}}$ & $0.58^{j}$ & $2.93^{\mathrm{bc}}$ \\
\hline 21 & $44,73 \pm 0,37^{\mathrm{k}}$ & $27,88 \pm 0,01^{\mathrm{ab}}$ & $27,45 \pm 0,1^{\mathrm{k}}$ & $7,16 \pm 0,2^{q}$ & $20,28 \pm 0,29^{j}$ & $24,65 \pm 0,04^{\mathrm{c}}$ & $0.61^{1}$ & $2.83^{b}$ \\
\hline 22 & $46,5 \pm 0,03^{n}$ & $31,36 \pm 0,09^{j}$ & $20,93 \pm 0,08^{\mathrm{a}}$ & $1,56 \pm 0,03^{\mathrm{a}}$ & $18,88 \pm 0,54^{\mathrm{c}}$ & $28,73 \pm 0,09^{p}$ & $0.56^{\mathrm{h}}$ & $14.73^{\mathrm{q}}$ \\
\hline 23 & $43,88 \pm 0,54^{\mathrm{hi}}$ & $28,22 \pm 0,19^{b}$ & $27,95 \pm 0,05^{1}$ & $6,14 \pm 0,08^{1}$ & $21,25 \pm 0,38^{\circ}$ & $24,59 \pm 0,28^{\mathrm{bc}}$ & $0.64^{\mathrm{n}}$ & $3.46^{\mathrm{d}}$ \\
\hline 24 & $45,11 \pm 0,29^{1}$ & $29 \pm 0,39^{c}$ & $24,83 \pm 0,19^{\mathrm{g}}$ & $4,28 \pm 0,07^{i}$ & $20,04 \pm 0,22^{1}$ & $27,12 \pm 0,17^{1}$ & $0.55^{\mathrm{g}}$ & $4.68^{h}$ \\
\hline 25 & $45,31 \pm 0,43^{\operatorname{lm}}$ & $28,36 \pm 0,28^{b}$ & $26,38 \pm 0,28^{1}$ & $6,75 \pm 0,28^{n}$ & $19,62 \pm 0,1^{\text {tg }}$ & $24,66 \pm 0,6^{\mathrm{c}}$ & $0.58^{\mathrm{j}}$ & $2.91^{\mathrm{bc}}$ \\
\hline 26 & $45,39 \pm 0,13^{\operatorname{lm}}$ & $27,91 \pm 0,17^{\mathrm{ab}}$ & $26,76 \pm 0,29^{j}$ & $2,23 \pm 0,01^{\mathrm{d}}$ & $24,51 \pm 0,05^{\mathrm{r}}$ & $25,19 \pm 0,34^{f}$ & $0.59^{\mathrm{k}}$ & $10.98^{\mathrm{n}}$ \\
\hline 27 & $43,59 \pm 0,31^{\text {fgh }}$ & $28,34 \pm 0,57^{b}$ & $28,14 \pm 0,29^{\mathrm{m}}$ & $6,96 \pm 0,32^{\mathrm{p}}$ & $21,17 \pm 0,3^{\mathrm{n}}$ & $24,75 \pm 0,32^{\mathrm{d}}$ & $0.65^{\circ}$ & $3.04^{\mathrm{c}}$ \\
\hline
\end{tabular}

Mean values with different letters in a column are significantly different $(P<0.05)$. nd: not detected. Codes: WF: wheat flour, SF: soybean flour, FF: flaxseed flour and WB: wheat bran, SFA: summation of saturated fatty acids, MU: summation of monounsaturated fatty acids, PUFAs: summation of polyunsaturated, PUFA/SFA: relationship polyunsaturated fatty acid and saturated fatty acids, $n 3$ : fatty acids of the $n 3$ family, n6: fatty acids of the $n 6$ family, $n 9$ : fatty acids of the $n 9$ family, n6/n3: relationship between fatty acids of series $n 6$ and $n 3$. 


\subsection{Technological Parameters}

Table 4 shows the values of specific volumes (SV), width/ height $(\mathrm{W} / \mathrm{H})$ ratios, moistures and water activities of the substituted breads with mixtures of flours. The WF replacement by flours blends in breads exerted significant differences in all studied parameters with respect to the control ( $\mathrm{p}<0.05)$. The volume is one of the most important characteristics of bread, as it provides a quantitative measure of baking performance. From the standpoint of consumers, the bread volume is also very important, since they wish a lighter bread and not very dense [28].

Table - 4: Values of specific volume (SV), width / height $(\mathrm{W} / \mathrm{H})$ ratio, moisture and water activity of the substituted bread with mixtures of flours

\begin{tabular}{|c|c|c|c|c|}
\hline Samples & SV & W/H & Moisture & aw \\
\hline 1 & $4,02 \pm 0,01^{\mathrm{a}}$ & $1,23 \pm 0,04^{j}$ & $32,52 \pm 0,2^{\text {bcdefg }}$ & $0,957 \pm 0,05^{\mathrm{jkI}}$ \\
\hline 2 & $3,95 \pm 0,09^{\mathrm{a}}$ & $1,43 \pm 0,12^{\mathrm{k}}$ & $36,25 \pm 0,27^{j}$ & $0,949 \pm 0,02^{\mathrm{f}}$ \\
\hline 3 & $4,51 \pm 0,12^{\text {cde }}$ & $1,23 \pm 0,18^{j}$ & $33,7 \pm 0,2^{\text {efghi }}$ & $0,945 \pm 0,01^{\mathrm{cd}}$ \\
\hline 4 & $4,55 \pm 0,17^{\text {cde }}$ & $1,21 \pm 0,28^{\mathrm{ij}}$ & $34,42 \pm 0,03^{\text {hij }}$ & $0,955 \pm 0,02^{\mathrm{ij}}$ \\
\hline 5 & $4,49 \pm 0,09^{\mathrm{cd}}$ & $1,05 \pm 0,18^{f}$ & $29,96 \pm 0,03^{\mathrm{a}}$ & $0,952 \pm 0,03^{\text {gh }}$ \\
\hline 6 & $4,35 \pm 0,03^{\mathrm{bc}}$ & $1,42 \pm 0,17^{\mathrm{k}}$ & $32,7 \pm 0,04^{\text {bcdefgh }}$ & $0,943 \pm 0,03^{\mathrm{bc}}$ \\
\hline 7 & $4,93 \pm 0,12^{f}$ & $1,15 \pm 0,06^{\text {gh }}$ & $33,3 \pm 0,01^{\text {defghi }}$ & $0,949 \pm 0,02^{\mathrm{f}}$ \\
\hline 8 & $4,97 \pm 0,32^{f}$ & $1,11 \pm 0,03^{\mathrm{g}}$ & $32,39 \pm 0,02^{\text {bcdefg }}$ & $0,942 \pm 0,02^{\mathrm{b}}$ \\
\hline 9 & $4,74 \pm 0,09^{\text {def }}$ & $1,17 \pm 0,03^{\text {hi }}$ & $32,17^{\text {bcdef }}$ & $0,936 \pm 0,02^{\mathrm{a}}$ \\
\hline 10 & $4,79 \pm 0,18^{\text {def }}$ & $1 \pm 0,02^{\mathrm{bcd}}$ & $33,14 \pm 0,02^{\text {cdefgh }}$ & $0,945 \pm 0,01^{\text {cd }}$ \\
\hline 11 & $4,93 \pm 0,02^{\mathrm{f}}$ & $1,05 \pm 0,03^{\mathrm{ef}}$ & $32,13 \pm 0,02^{\text {bcde }}$ & $0,953 \pm 0,09^{\text {hi }}$ \\
\hline 12 & $4,52 \pm 0,02^{\text {cde }}$ & $1 \pm 0,02^{\text {bcde }}$ & $32,6 \pm 0,01^{\text {bcdefgh }}$ & $0,95 \pm 0,02^{\mathrm{fg}}$ \\
\hline 13 & $4,78 \pm 0,03^{\text {def }}$ & $0,96 \pm 0,02^{\mathrm{b}}$ & $35 \pm 0,01^{\mathrm{ij}}$ & $0,95 \pm 0,07^{\mathrm{fg}}$ \\
\hline 14 & $4,48 \pm 0,01^{\text {bcd }}$ & $0,89 \pm 0,01^{\mathrm{a}}$ & $31,64^{\text {abcd }}$ & $0,959 \pm 0,01^{\mathrm{Im}}$ \\
\hline 15 & $3,93 \pm 0,4^{\mathrm{a}}$ & $0,97 \pm 0,06^{\mathrm{bc}}$ & $33,61 \pm 0,02^{\text {efghi }}$ & $0,957 \pm 0,02^{\mathrm{jkI}}$ \\
\hline 16 & $4,78 \pm 0,05^{\mathrm{def}}$ & $1,01 \pm 0,04^{\text {cdef }}$ & $33,05 \pm 0,02^{\text {cdefgh }}$ & $0,958 \pm 0,04^{\mathrm{km}}$ \\
\hline 17 & $4,68 \pm 0,12^{\mathrm{def}}$ & $1,11 \pm 0,01^{\mathrm{g}}$ & $32,78 \pm 0,02^{\text {bcdefgh }}$ & $0,946 \pm 0,01^{\mathrm{de}}$ \\
\hline 18 & $4,81 \pm 0,02^{\mathrm{ef}}$ & $1,16 \pm 0,02^{\text {hi }}$ & $32,44 \pm 0,01^{\text {bcdefg }}$ & $0,96 \pm 0,02^{\mathrm{mn}}$ \\
\hline 19 & $4,36 \pm 0,03^{\mathrm{bc}}$ & $0,99 \pm 0,04^{\text {bcd }}$ & $32,19 \pm 0,02^{\text {bcdef }}$ & $0,948 \pm 0,01^{\mathrm{ef}}$ \\
\hline 20 & $4,49 \pm 0,03^{\text {bcd }}$ & $0,98 \pm 0,01^{\text {bcd }}$ & $31,43 \pm 0,01^{\mathrm{abc}}$ & $0,95 \pm 0,02^{\mathrm{fg}}$ \\
\hline 21 & $4,18 \pm 0,12^{\mathrm{ab}}$ & $1,02 \pm 0,01^{\text {def }}$ & $33,02 \pm 0,07^{\text {cdefgh }}$ & $0,948 \pm 0,01^{\text {ef }}$ \\
\hline 22 & $4,95 \pm 0,01^{\mathrm{f}}$ & $1,02 \pm 0,02^{\text {def }}$ & $33,98 \pm 0,56^{\text {fghi }}$ & $0,962 \pm 0,01^{\mathrm{n}}$ \\
\hline 23 & $4,73 \pm 0,02^{\mathrm{def}}$ & $1,11 \pm 0,02^{\mathrm{g}}$ & $30,22 \pm 0,05^{\mathrm{a}}$ & $0,949 \pm 0,11^{\mathrm{f}}$ \\
\hline 24 & $4,74 \pm 0,03^{\text {def }}$ & $1,06 \pm 0,01^{\mathrm{f}}$ & $34,15 \pm 0,01^{\text {ghi }}$ & $0,955 \pm 0,01^{\mathrm{ij}}$ \\
\hline 25 & $4,82 \pm 0,02^{\mathrm{ef}}$ & $0,98 \pm 0,2^{\mathrm{bcd}}$ & $33,63 \pm 0,21^{\text {efghi }}$ & $0,958 \pm 0,07^{\mathrm{km}}$ \\
\hline 26 & $4,56 \pm 0,03^{\text {cde }}$ & $0,99 \pm 0,02^{\text {bcd }}$ & $32,37 \pm 0,19^{\text {bcdefg }}$ & $0,956 \pm 0,09^{\mathrm{jk}}$ \\
\hline 27 & $4,71 \pm 0,02^{\text {def }}$ & $1,03 \pm 0,09^{\text {def }}$ & $31,16 \pm 0,01^{a b}$ & $0,959 \pm 0,01^{\operatorname{lm}}$ \\
\hline
\end{tabular}

Mean values with different letters in a column are significantly different $(P<0.05)$. nd: not detected. Codes: WF: wheat flour, SF: soybean flour, FF: flaxseed flour and WB: wheat bran

The results showed that SV of the loaves substituted with a type of flour, with mixtures of two flours (with FF in medium and high level), and only one with the blend of three flours (FF and SF with medium levels and WB with high level), did not present significantly differences ( $p$ $<0.05$ ) with respect control.

While the replacement with blends of three flours increased the breads weight and decreased breads volume, which led to decreased loaf specific volumes. Therefore, the addition of mixtures of three flours produced a significant decrease in specific volumes of substituted loaves.

This could be because of the dilution of gluten that causes less gas retention and consequently a lower volume.

These results were consistent with Conforti and Davis [29] and also Chinma et al. [30]. Conforti and Davis [29] reported that flax and soya flours caused a decrease in loaf volume, while Chinma et al. [30] found that in the mixed breads, the specific volume decreased from 3.02 to $2.93 \mathrm{~cm}^{3}$ $\mathrm{g}$ when blend of flours were added at sourdough, compared with $100 \%$ wheat flour breads $\left(3.17 \mathrm{~cm}^{3} / \mathrm{g}\right)$.

Moreover, the presence of wheat bran in the mass may avoid proper development of the gluten network and cause rupture of the gas cells [31]. Indrani et al. [32] found that the multigrain mix (soy, oats, fenugreek seeds, flax seeds and sesame) exerted an adverse effect on the volume of bread due to that the increasing amounts of multigrain mixture of $0-20 \%$ caused the interruption matrix protein and the reduction of specific volume.

Alaunyte et al. [33] also reported that the decrease in bread volume supplemented with teff sourdough, was attributed to the presence of bran particles of the teff flour in the matrix of gluten in the dough. Even more, differences in the 
composition of lipids cause destabilization of gas cells so that might contribute to the alterations in bread volume too.

The width/high $(\mathrm{W} / \mathrm{H})$ ratio of bread provides information on the shape thereof. A high $\mathrm{W} / \mathrm{H}$ indicates a flat bread, while a lower $\mathrm{W} / \mathrm{H}$ corresponds to a bread with greater height and better provided [34]. The results showed that two formulations (samples number 2 and number 6) presented a high $\mathrm{W} / \mathrm{H}$ ratio, being these accompanied for greater decrease of SV; consequently, these loaves were more flattened. The others loaves presented a W/H ratio somewhat smaller than control, but these were not accompanied by a large decrease in the SV, turning out to be breads higher than wide.

The international regulations establish that the moisture must be minor $40 \%$ for whole bread, therefore all samples, including control are within the limits of international regulations. Breads with FF high concentrations tended to decrease moisture of the loaves replaced, it is according with Bautista Justo [23], who reported that the moisture of whole grain breads with soy, chia, flax and folic acid ranged from $32 \%$ (breads with whole wheat flour) to $27.7 \%$ (breads with $20 \%$ of mixtures of SF, FF and chia); showing a decrease of moisture in substituted loaves.

\subsection{Selected Formulations}

Two optimal formulations with high content $\mathrm{n} 3$ and good specific volume (similar to the control) were selected. The

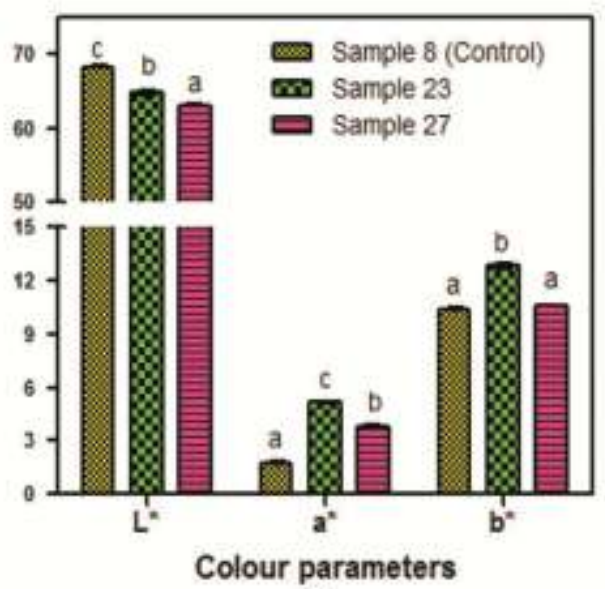

(a) first sample (number 23) was prepared with $16 \mathrm{gFF} / \mathrm{kg} \mathrm{WF}$ and $16 \mathrm{gWB} / \mathrm{kg} \mathrm{WF}$ and the second sample (number 27) was elaborated with $16 \mathrm{gFF} / \mathrm{Kg} \mathrm{WF}$ and $8 \mathrm{gSF} / \mathrm{Kg} \mathrm{WF}$.

\subsection{Colour Measurement}

Figure 1 presents colour measurement of crumb and crust of control and of selected samples. The parameter $\mathrm{L}^{*}$ and $\mathrm{a}^{*}$ of crumb of selected breads presented significant differences with control (Figure 1a), being both breads less luminous than control. The crumb colour in bread with FF and WB was more reddish and presented the highest value $\mathrm{a}^{*}$, while the crumb of bread with FF and SF was the most yellowish.

Colour bread crust is one of the most important parameters in the choice by consumers. The type of flour, the quality and quantity of ingredients used, as well as the cooking temperature and time influence the final colour of the crust [35].

The $\mathrm{L}^{*}$ values of the crust of substituted breads (Figure 1b) were significantly lower than the control; exhibiting the darkest crusts. Since temperature and baking time were maintained constant for all formulations made, the visible colour variations in the crust of functional bread compared to the control bread, we can deduce that this is due to the changes in the formulations.

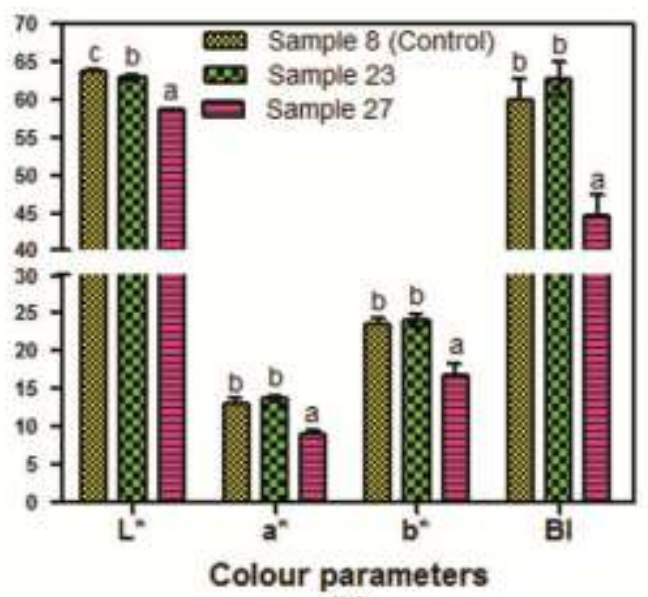

(b)

Fig -1: Colour parameters of crumb and crust of the control and of selected samples.

On the other hand, $\mathrm{a}^{*}$ and $\mathrm{b}^{*}$ of the sample with $16 \mathrm{~g} \mathrm{FF} / \mathrm{kg}$ $\mathrm{WF}$ and $16 \mathrm{~g} \mathrm{WB} / \mathrm{kg}$ WF did not exhibit differences with control. In a like manner, the browning index (BI) of this sample was similar to the control. This parameter is an important for quality of baked products, in relation to the Maillard reactions due to that shows the purity of brown [36].

These results are according with [29]whose reports indicate that as flax meal and soya flour are darker than wheat flour, it would be expected that the crumb colour would darken with the addition of these ingredients.Santos Calderelli et al. [37]also found that the bread colour with FF (crust and crumb) was darker that bread with quinoa flour.

\subsection{Texture Profile Analysis of Crumb Breads}

Figure 2 presents texture profile analysis of crumb of control sample and of the two selected samples.

The texture parameters (hardness and chewiness) of the selected samples presented significant differences with control. However, sample number 27 did not show differences in cohesiveness and springiness. The sample with $16 \mathrm{gFF} / \mathrm{kg} \mathrm{WF}$ and $16 \mathrm{gWB} / \mathrm{kg}$ WFpresented harder 
crumb, less cohesiveness and most chewiness than control. WB was the factor that exerted the greatest effect on these textural characteristics.

Majzoobi et al. [38] showed that bread with WB was harder and less consistent when increased the fibre content in the dough of flat bread. In studies conducted by Davis [39], the texture of the control bread was significantly softer than breads containing FF and/or SF. Staling and moisture migration seemed to occur more easily in the breads containing FF and SF, giving a firmer texture. Since the volume of bread containing FF and/or SF was also significantly lower than control, more compressed crumb may also have contributed to a firmer texture.

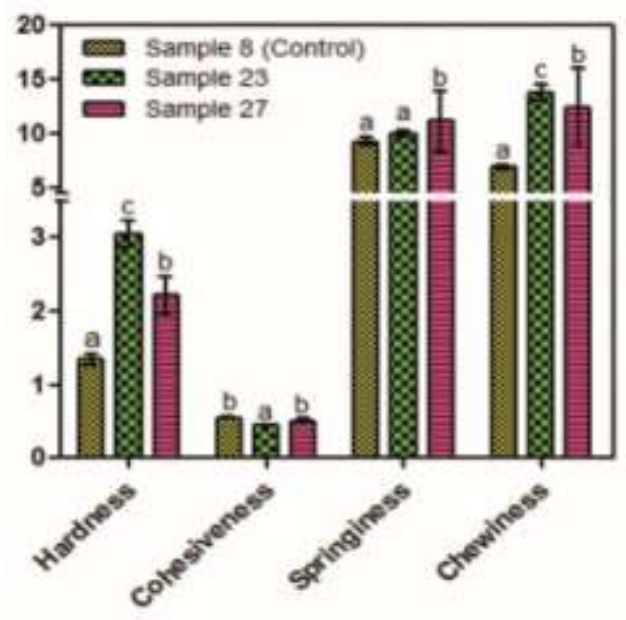

Fig -2: Textural parameters of crumb of control sample and of the two selected samples

\section{CONCLUSION}

The replacement of wheat flour by mixtures of three flours (FF, SF and WB) at the bread formulation, affected both the fatty acid profile as the technological, colour and textural characteristics.

Two formulations were selected for its high n3 fatty acid content, one prepared with $16 \mathrm{~g} \mathrm{FF} / \mathrm{kg} \mathrm{WF}$ and $16 \mathrm{~g} \mathrm{WB} / \mathrm{kg}$ $\mathrm{WF}$ (sample number 23) and the second elaborated with 16 gFF/Kg WF and 8 gSF/Kg WF (sample number 27).

\section{ACKNOWLEDGEMENT}

This research was supported by Universidad Nacional de Chaco Austral, and Consejo Nacional de InvestigacionesCientíficas y Tecnológicas (CONICET), Argentina.

\section{REFERENCES}

[1] U. Gawlik-Dziki, D. Dziki, M. Świeca, Ł. Sęczyk, R. Różyło, and U. Szymanowska, "Bread enriched with Chenopodium quinoa leaves powder - The procedures for assessing the fortification efficiency," LWT - Food Sci. Technol., vol. 62, no. 2, pp. 12261234, 2015.

[2] M. Hao and T. Beta, "Development of Chinese steamed bread enriched in bioactive compounds from barley hull and flaxseed hull extracts," Food Chem., vol. 133, no. 4, p. 1320e1325, 2012.

[3] F. Yuksel, S. Karaman, and A. Kayacier, "Enrichment of wheat chips with omega-3 fatty acid by flaxseed addition: textural and some physicochemical properties.," Food Chem., vol. 145, pp. 910-7, 2014.

[4] A. Goyal, V. Sharma, N. Upadhyay, S. Gill, and M. Sihag, "Flax and flaxseed oil: an ancient medicine \& amp; modern functional food," J. Food Sci. Technol., vol. 51, no. 9, pp. 1633-1653, 2014.

[5] M. Lazo-Vélez, C. Chuck-Hernandez, and S. SernaSaldívar, "Evaluation of the functionality of five different soybean proteins in yeast-leavened pan breads," J. Cereal Sci., vol. 64, pp. 63-69, 2015.

[6] M. Mahmoodi, M. Mashayekh, and M. Entezari, "Fortification of wheat bread with 3-7\% defatted soy flour improves formulation, organoleptic characteristics, and rat growth rate," Internaional $J$. Prev. Med., vol. 5, pp. 37-45, 2014.

[7] N. Mateo Anson, R. van den Berg, R. Havenaar, A. Bast, and G. Haenen, "Ferulic acid from aleurone determines the antioxidant potency of wheat grain (Triticum aestivum L.)," J. Agric. Food Chem., vol. 56, no. 14, pp. 5589-94, 2008.

[8] M. Prückler, S. Siebenhandl-Ehn, S. Apprich, S. H€oltinger, C. Haas, E. Schmid, and W. Kneifel, "Wheat bran-based biorefinery 1: composition of wheat bran and strategies of functionalization," $L W T$ Food Sci. Technol., vol. 56, pp. 211-221, 2014.

[9] B. Laddomada, S. Caretto, and G. Mita, "Wheat Bran Phenolic Acids: Bioavailability and Stability in Whole Wheat-Based Foods," Molecules, vol. 20, no. 9, pp. 15666-15685, 2015.

[10] M. Prückler, C. Lorenz, A. Endo, M. Kraler, K. Dürrschmid, K. Hendriks, F. Soares da Silva, E. Auterith, W. Kneifel, and H. Michlmayr, "Comparison of homo- and heterofermentative lactic acid bacteria for implementation of fermented wheat bran in bread," Food Microbiol., vol. 49, pp. 211$219,2015$.

[11] C. Sherry, J. Oliver, and B. Marriage, "Docosahexaenoic acid supplementation in lactating women increases breast milk and plasma docosahexaenoic acid concentrations and alters infant omega 6:3 fatty acid ratio.," Prostaglandins. Leukot. Essent. Fatty Acids, vol. 95, pp. 63-9, 2015.

[12] A. Simopoulos, "The Importance of the Omega6/Omega-3 Fatty Acid Ratio in Cardiovascular Disease and Other Chronic Diseases," Exp. Biol. Med., vol. 233, no. 6, pp. 674-688, 2008.

[13] M. Irakli, D. Katsantonis, and F. Kleisiaris, "Evaluation of quality attributes, nutraceutical components and antioxidant potential of wheat bread substituted with rice bran," J. Cereal Sci., vol. 65, pp. 74-80, 2015.

[14] E. Hernandez, "Enrichment of baked goods with omega-3 fatty acids," in Food enrichment with omega-3 fatty acids, Woodhead Publishing Limited, 2013, pp. 319-335. 
[15] AACC, Approved Methods of the American Association of Cereal Chemists, 9th Editio. USA, 2000.

[16] M. Osuna, M. Judis, A. Romero, C. Avallone, and N. Bertola, "Improvement of Fatty Acid Profile and Studio of Rheological and Technological Characteristics in Breads Supplemented with Flaxseed, Soybean, and Wheat Bran Flours," Sci. World J., vol. 2014, 2014.

[17] E. Bligh and W. Dyer, "A rapid method of total lipid extraction and purification," Can. J. Biochem. Physiol., vol. 37, no. 8, pp. 911-917, 1959.

[18] AOAC, Official Methods of Analysis of Official Analytical Chemist, 16th editi. Washington, DC, USA: AOAC, 1995.

[19] M. Romero, A. Romero, M. Doval, and M. Judis, "Nutritional value and fatty acid composition of some traditional Argentinean meat sausages," Food Sci. Technol., vol. 33, no. 1, pp. 161-166, 2013.

[20] M. Fik, K. Surówka, I. Maciejaszek, M. Macura, and M. Michalczyk, "Quality and shelf life of calciumenriched wholemeal bread stored in a modified atmosphere," J. Cereal Sci., vol. 56, no. 2, pp. 418424, Sep. 2012.

[21] D. Komlenić, Ž. Ugarčić-Hardi, M. Jukić, M. Planinić, A. Bucić-Kojić, and I. Strelec, "Wheat dough rheology and bread quality effected by Lactobacillus brevis preferment, dry sourdough and lactic acid addition," Int. J. Food Sci. Technol., vol. 45, no. 7, pp. 1417-1425, 2010.

[22] M. Lutz and A. Leon, Aspectos nutricionales y saludables de los productos de panificación, Universida. Cordoba, 2009.

[23] M. Bautista Justo, D. Castro Alfaro, E. C. Aguilar, K. Wrobel, K. Wrobel, G. Guzman, Z. Gamiño Sierra, and V. Da Mota Zanella, "Desarrollo de pan integral con soya , chía , linaza y ácido fólico como alimento funcional para la mujer," Arch. Latinoam. Nutr., vol. 57, no. 3, 2007.

[24] D. Gomes Natal, M. De Souza, M. Teixeira Ribeiro Vidigal, R. Ribeiro Silva, and H. Duarte Martino, "Physical and sensorial properties of potato breads fortified with whole soybean flour," Rev. Chil. Nutr., vol. 40, no. 1, pp. 62-70, 2013.

[25] I. Soto-Rodríguez, E. Pulido-Camarillo, G. Hernández-Diaz, A. Alexander-Aguilera, and H. S. Garcia, "A CLA enriched diet improves organ damage associated with the metabolic syndrome in spontaneous hypertensive rats," Grasas y aceites, vol. 62, no. 1, pp. 49-54, 2011.

[26] A. Simopoulos, "Evolutionary Aspects of Diet: The Omega-6 / Omega-3 Ratio and the Brain," Mol. Neurobiol., vol. 44, pp. 203-215, 2011.

[27] OMS, Fats and fatty acids in human nutrition. 2008.

[28] K. Tronsmo, E. Færgestad, J. Schofield, and E. Magnus, "Wheat protein quality in relation to baking performance evaluated by the Chorleywood bread process and a hearth bread baking test," J. Cereal Sci., vol. 38, no. 2, pp. 205-215, Sep. 2003.

[29] F. Conforti and S. Davis, "The effect of soya flour and flaxseed as a partial replacement for bread flour in yeast bread," Int. J. Food Sci. Technol., vol. 41, no. 2, pp. 95-101, Dec. 2006.

[30] C. Chinma, J. Anuonye, B. Ocheme, S. Abdullahi, S. Oni, C. Yakubu, and S. Azeez, "Effect of acha and bambara nut sourdough fl our addition on the quality of bread," LWT - Food Sci. Technol., vol. 70, pp. 223-228, 2016.

[31] M. Mariotti, C. Garofalo, L. Aquilanti, A. Osimani, L. Fongaro, S. Tavoletti, A. Hager, and F. Clementi, "Barley fl our exploitation in sourdough breadmaking: A technological, nutritional and sensory evaluation," LWT - Food Sci. Technol., vol. 59, no. 2, pp. 973-980, 2014.

[32] D. Indrani, C. Soumya, J. Rajiv, and G. Venkateswara Rao, "Multigrain Bread - Its Dough Rheology, Microstructure, Quality and Nutritional Characteristics," J. Texture Stud., vol. 41, no. 3, pp. 302-319, Apr. 2010.

[33] I. Alaunyte, V. Stojceska, A. Plunkett, P. Ainsworth, and E. Derbyshire, "Improving the quality of nutrient-rich teff breads by combination of enzymes in straight dough and sourdough breadmaking," $J$. Cereal Sci., vol. 55, no. 1, pp. 22-30, 2012.

[34] G. Pérez García, "Efecto del uso de Hidrocoloides en la calidad sensorial y las propiedades de pan de sal recalentado en horno de microondas," Universidad de las Américas Puebla, 2008.

[35] M. Salinas, A. Zuleta, P. Ronayne, and M. Puppo, "Wheat bread enriched with organic calcium salts and inulin . A bread quality study," J. Food Sci. Technol., 2015.

[36] C. Saricoban and M. Yilmaz, "Modelling the effects of processing factors on the changes in colour parameters of cooked meatballs using response surface methodology," World Appl. Sci. J., vol. 9, no. 1, pp. 14-22, 2010.

[37] V. Santos Calderelli, M. Toledo, J. Visentainer, and G. Matioli, "Quinoa and flaxseed: Potential ingredients in the production of bread with functional quality," Brazilian Arch. Biol. Technol., vol. 53, no. 4, pp. 981-986, 2010.

[38] M. Majzoobi, A. Farahnaky, Z. Nematolahi, M. Hashemi Mohammadi, and J. Taghipour Ardakani, "Effect of Different Levels and Particle Sizes of Wheat Bran on the Quality of Flat Bread," J. Agric. Sci. Technol., vol. 15, pp. 115-123, 2013.

[39] S. F. Davis, "The effect of soy flour as a natural antioxidant on flaxseed in yeast bread," Faculty of Virginia Polytechnic Institute and State University, 2004. 